\title{
First generation highways. Participation loans valuation in the framework of real options
}

\section{Autovías de primera generación. Valoración de los préstamos participativos en el marco de las opciones reales}

Antonio L. Lara-Gallera (Main and Contact Author)

Universidad Politécnica de Madrid. Dpto. de Ingeniería de la Construcción. Escuela Técnica Superior de Ingenieros de Caminos, Canales y Puertos.

+34915498691. C/ Profesor Aranguren s/n. 28040 Madrid

alargal@ciccp.es

\section{Antonio Sánchez-Soliño}

Universidad Politécnica de Madrid. Dpto. de Ingeniería de la Construcción. Escuela Técnica Superior de Ingenieros de Caminos, Canales y Puertos.

asanoli@ciccp.es

\section{Rubén Galindo-Aires}

Universidad Politécnica de Madrid. Dpto. de Ingeniería y Morfología del Terreno. Escuela Técnica Superior de Ingenieros de Caminos, Canales y Puertos.

rubenangel.galindo@upm.es

Manuscript Code: 644

Date of Acceptance/Reception: 01.08.2016/29.05.2015

\section{Abstract}

The concept of highway has been applied in Spain to a high capacity road that does not meet all the requirements of motorways. The Strategic Plan of Infrastructure and Transport 2005-2020 has tackled as a priority the reform of these infrastructures in the form of public works concessions, remunerating the concessionaire using a shadow toll scheme. As part of the project financing, concession companies had public equity loans to finance initially unforeseen works. Traditional methods of investment valuation do not quantify accurately the extent and effectiveness of such measures. The aim of this study is to provide a methodology based on the real options theory to quantify the real value provided by these loans to concessionaires. The study shows that this type of public loans adds an important value to the contracts. So, an adequate design of this financial support must be considered in order to have a balanced sharing of risks.

Keywords: real option, participation loan, highway, motorway, concession.

Resumen

El concepto de autovía se ha aplicado en España a una vía de alta capacidad, que no reúne todos los requisitos de las autopistas. El Plan Estratégico de Infraestructuras y Transporte 2005-2020 ha abordado con carácter prioritario la reforma de estas infraestructuras en forma de concesión de obra pública, remunerando al concesionario mediante un peaje en sombra. Como parte de la financiación del proyecto, las sociedades concesionales tuvieron préstamos participativos del Estado para financiar las obras no previstas inicialmente. Los métodos tradicionales de valoración de inversiones no permiten valorar de manera precisa este tipo de medidas. El objetivo de este trabajo es aportar una metodología basada en la teoría de opciones reales para cuantificar el valor de estos préstamos. Los resultados muestran que estas ayudas aportan un valor importante al concesionario, por lo que la Administración debe diseñarlas adecuadamente para que haya un reparto equitativo de riesgos.

\section{Description of the problem}

The concept of "first generation highway (autovía de primera generación) has been applied in Spain to a high capacity road that does not meet all the requirements of motorways (autopistas). The Plan General de Carreteras 1984-1991 devoted a specific program to this type of roads, pursuing to increase the network capacity, reduce travel times and improve road safety (Ministerio de Obras Públicas y Urbanismo, 1984). However, all the projects of highways were initially developed as a splitting of existing roads, in order to reduce costs, so their standards were quite away from those of toll motorways.

These highways early began to present problems: rapid deterioration of the pavements, lack of capacity in some sections, accidents, etc. (Sanchez Solino, Vassallo, Castroman, \& Delgado, 2007). The Strategic Plan of Infrastructure and Transport (PEIT) 2005-2020 has tackled as a priority the reform of these infrastructures. This plan presents the particularity that the proposed actions are held in the form of public works concessions, remunerating the concessionaire through a shadow toll scheme. 
During the implementation of the concession contracts, additional works appeared not initially foreseen. This increased the planned investment and changed the economic and financial balance of the concession contracts. In this context, the Administration offered participation loans to concessionaires in order to finance unanticipated works. In this type of loan, the lender's remuneration is linked to the economic performance of the contract, so the interest paid by the concessionaire will depend mainly on the traffic volume with an optional character.

The valuation of an equity loan by traditional valuation procedures is difficult, since it requires setting the traffic evolution over time in order to estimate cash-flows, and determining an appropriate discount rate. The most appropriate way to value a participation loan is to use the real options theory, since payments are tied to the future evolution of the volume of traffic and the conditions of exercise depend on the course of events.

State of the art

There is a growing literature on government guarantees in concession contracts. One stream of research focuses on how government guarantees can reduce project risks. Wibowo (2004) studied the financial impact of government guarantees on project cash flows and concluded that government guarantees were more effective than direct subsidies in reducing project risks. Vassallo and Sánchez Soliño (2006) specifically investigated the mechanism of minimum revenue guarantee in mitigating traffic risk. Another group of research investigates the optimal guarantee level. For instance, by taking into account shadow cost of public funds and private investors' risk aversion, (Engel et al., 2013) gave the optimal guarantee level under minimum revenue guarantee for intermediate-demand road projects. Finally, there is a number of studies undertaken recently to examine the option value of government guarantees by employing real option models (Ashuri et al., 2012; Brandao and Saraiva, 2008; Lara Galera and Sánchez Soliño, 2010).

The aim of this study is to provide a methodology based on the real options framework to quantify the real value provided by participation loans to concessionaires, or, from another perspective, to quantify the true cost they represent to the public sector.

\section{Concession contracts for the renovation of the first generation highways}

The purpose of these contracts is to update these infrastructures, undertaking maintenance and renovation works. Taking into account the budgetary restrictions, the Administration proposed the development of such works via the concession system, with a payment scheme based on shadow tolls. In this scheme, the private sector designs, finances, builds and operates an infrastructure. In return, the public sector pays periodically, via the General Government Budget, an agreed quantity in the concession contract based on the actual use of the infrastructure. Furthermore, these contracts have added a new and extensive system of quality indicators that penalizes income if management departs from certain quality standards.

\section{Projected investment}

Table 1. Sections in the priority corridors. Source: Ministerio de Fomento, 2007

\begin{tabular}{|c|l|c|}
\hline ROAD & SECTION & KILOMETERS \\
\hline \multirow{4}{*}{ A1 } & A1: Madrid - Santo Tomé del Puerto & 89 \\
\cline { 2 - 3 } & A1: Santo Tomé del Puerto - Burgos & 146 \\
\hline \multirow{5}{*}{ A3 } & A2: Madrid - p.k. 62 (R2) & 57 \\
\cline { 2 - 3 } & A2: p.k. 62 (R2) - L.P. Soria/Guadalajara & 76 \\
\cline { 2 - 3 } & A2: L.P. Soria/Guadalajara - Calatayud & 95 \\
\cline { 2 - 3 } & A2: Calatayud - Alhajarán & 107 \\
\cline { 2 - 3 } & A3: Madrid - L.P. Cuenca & 68 \\
\cline { 2 - 3 } & $\begin{array}{l}\text { A3: L.P. Madrid/Cuenca L.P. Cuenca/Albacete } \\
\text { A4 }\end{array}$ & 141 \\
\cline { 2 - 3 } & A31: L.P. Albacete (La Roda) - Bonete & 94 \\
\cline { 2 - 3 } & A31: Bonete - Alicante & 111 \\
\hline & A4: Madrid - p.k. 67,5 (R4) & 70 \\
\cline { 2 - 3 } & A4: p.k. 67,5 (R4) - Puerto Lapice & 107 \\
\cline { 2 - 3 } & $\begin{array}{l}\text { A4: Puerto Lápice - L.P. Jaén (Venta de } \\
\text { Cárdenas) }\end{array}$ & 102 \\
\cline { 2 - 3 } & A4: L.P. Jaén/Ciudad Real - L.P. Córdoba/Jaén & 105 \\
\cline { 2 - 3 } & A4: L.P Córdoba/Jaén - L.P. Sevilla/Córdoba & 1.521 \\
\cline { 2 - 3 } & A4: L.P. Sevilla/Córdoba - Sevilla. & \\
\hline & Collect & \\
\hline
\end{tabular}


The planned investment for the whole program amounts to 5,392 million euros. The budget for the initial improvement and reform works is 2,877 million euros, of which 1,986 correspond to a first phase. The table shows the sections presented and definitively undertaken (shaded).

\section{General approach to contracts}

The contracts include works that are described as first establishment, reform, major repair, simple repair, conservation and maintenance, as well as the operation of the infrastructure throughout the concession period (19 years). The payment by the public administration is based on shadow tolls, taking into account the quality of the service, and, during the first years of the contract, the percentage of completed works. The contract states that the concessionaire assumes all project risks: design, expropriations and affected services modifications, construction works, maintenance, financing and operation of the highway and, in general, all the necessary activities required to carry out the contract.

\section{Economic-financial regime of contracts}

The Administration pays a monthly "demand fee". During the first year, the concessionaire has no right to receive any economic retribution. In the following years, while construction works take place, the canon is calculated applying to the base demand fee a percentage that depends on the investment in works that are in operation in the previous year. In the event that a given annual maximum traffic limit is exceeded, a percentage of the unit rate offered will be applied to the surplus of vehicle-kilometers. This percentage turned out to be $0 \%$ in all offers.

The demand fee will therefore be determined by: The vehicle category: light or heavy. The amount of the heavy vehicles rate is $40 \%$ higher than that of light ones. The number of vehicle-kilometers of each type circulating on the motorway. The offered rate applicable to each type of vehicle per kilometer travelled. The correction factors related to the mentioned quality indicators. The update rates, based on the Consumer Price Index (CPI) evolution.

\section{Maintenance of the financial and economic balance}

According to the Public Sector Contracts Law, the Administration must restore the economic and financial balance of the contract in the following scenarios: When modifications are made in the projects, approved in the cases stated by law. When the administration changes, on grounds of public interest, the operating conditions of the contract. When force majeure or actions of the Administration, determine in a direct way the substantial change of the concession's economy.

\section{Amendments to the concession contracts}

During the course of the works, needs not initially foreseen emerged, which resulted in an increase of the investment and altered the economic and financial balance of the contracts. In order to restore the concessional financial balance, the Administration approved an increase in the rate charged by the concessionaire, in accordance with the new financial plans and maintaining the Internal Rate of Return (IRR) provided in the offer. In addition, the Administration also offered the aforementioned participation loans. The loans would only be granted for the amount corresponding to such economic increase.

Participation loans

Participation loans are described in article 20 of Royal Decree-Law 7/1996 of 7 June (BOE, 1996), which states the following characteristics:

- The lender shall receive a variable interest that is determined by the evolution of the activity of the borrowing company.

- The contracting parties may agree on a penalty clause for early repayment. In any case, the borrower may only amortize in advance the participating loan if this repayment is compensated by an increase of the same amount of their own funds and if it does not come from updating assets.

- Participation loans, in terms of credit priority, will be placed after the common creditors.

- The participation loans are considered equity for the purpose of capital reduction and liquidation of companies under mercantile legislation. Therefore, although they are considered liabilities for accounting purposes, they enjoy a special consideration when assessing the financial situation of the borrower company in situations of undercapitalization. 
In the case of first generation highways, it was planned the granting of these loans from the State Budget 2010 (BOE, 2009) and 2011 with a total budgetary allocation of 400 million euros, although finally the full amount was paid from the 2011 budget. A description of the participation loans mechanism applied to road concessions can be found in Izquierdo and Vassallo (2004) and Vassallo and Sánchez Soliño (2007).

\section{Terms of remuneration of the loan}

The main features of the loan for first generation highways are:

- $\quad$ The loan period is the remainder of the concession term.

- The repayment of principal will be made in a single payment, six months before the end of the concession (except if early amortization is authorized).

- $\quad$ Regarding the remuneration of the loan, the state will receive, accrual at December 31 of each year, from the date of disbursement, the largest of the following amounts:

0 The amount obtained by applying a fixed rate of interest of 175 basis points on the outstanding balance of the participation loan.

o The amount obtained by applying the following formula:

$$
R=0,5 \times T \times \frac{C a R}{C a M} \times P P
$$

Where: $R$ = annual remuneration; $T$ = project IRR before tax; $C a R=$ real annual demand fee; CaM = maximum annual demand fee; $P P=$ outstanding balance from the granted participation loan.

In the specifications that regulate each of the ten existing contracts for first generation highways, the monthly fee is defined as the result of multiplying the value of the current rate (updated with the corresponding CPI) and corrected (according to fulfillment of quality indicators described in the Sheet itself) for each vehicle type (light or heavy) by the number of vehicle-kilometers for each one of the two types of vehicles considered.

$$
\text { Canon }=T p \times V k m p+T l \times V k m l
$$

Where: $\mathrm{Tp}=$ corrected rate for heavy vehicles; $\mathrm{Vkmp}=$ number of heavy vehicles by kilometers travelled; $\mathrm{Tl}=$ corrected rate for light vehicles; $\mathrm{Vkml}=$ number of light vehicles by kilometers travelled.

This means that the remuneration of the loan depends on the traffic passing through the highway section subject to the contract. In addition, a grace period of three years for the payment of the remuneration of the loan is established. The accrued interest in this period will be capitalized along with the principal, considered as such for all purposes. The loan will appear separately as a variable interest loan in the long-term liabilities of the balance sheet. The debt to the State shall be classified as subordinated debt, except in relation to any non-privileged credits that correspond to the shareholders.

\section{Methodology}

Given that the compensation of participation loans granted by the State depends on traffic, it is essential to define the traffic evolution over time.

\section{Data used}

The Annual Average Daily Traffic (AADT) has been extracted from the principal roads of the Spanish Network for light and heavy vehicles. Once AADT data are gathered by gauging stations per year, for light and heavy vehicles and in both traffic directions, we calculated a representative AADT for a road section subject of a concession contract for each registered year. Therefore, two parallel calculations have been made: 


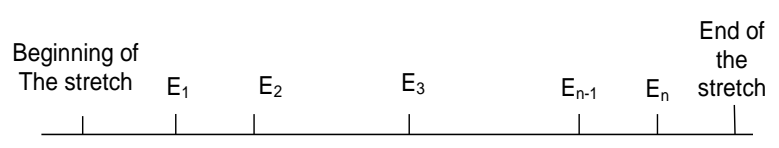

- As a first option, the AADT is calculated on the road stretch En - En-1 as the arithmetic mean of registered traffic En and registered $E n-1$, whenever there is registration of the two gauging station. If one of them (En for example) is not registered, the traffic would be recorded at the other end. This traffic value would be applied consistently in the stretch En - En-1.

- As a second possibility, the recorded AADT is applied in the station En-1 to the stretch En - En-1. To choose a representative AADT of the section subject of the concession contract, it has been estimated an average of all AADT for each subsection En - En-1, weighted with the length of each subsection. Once these two possibilities of vehicles intensity are obtained, the results have been compared to the AADT value provided by the most recent Traffic Maps, published by the Ministerio de Fomento (2000-2009), being the second option considered more accurate.

\section{Traffic characterization}

The fundamental parameters that will characterize traffic flows on a particular stretch, according to the methodology developed below, are the average annual growth in traffic and the average annual traffic volatility, defined in the following way:

Being $\theta 0, \theta 1, \theta 2, \ldots, \theta n, n+1$ values of the traffic on a highway that correspond to the years $0,1,2, \ldots, n$. Traffic growth between any consecutive two years expressed in per unit will be defined by: $\mathrm{ci}=\theta \mathrm{i} / \theta_{\mathrm{i}-1} \mathrm{and}$ their average growth rate until any given year " $\mathrm{j}$ " by: $\alpha \mathrm{j}$, media $=-1+(1 / \mathrm{j})(\mathrm{c} 1+\mathrm{c} 2+\mathrm{c} 3+\ldots+\mathrm{cj})$.

To calculate traffic volatility, we have proceeded by analogy with the financial variables. Among the existing procedures to determine the volatility of a financial variable, the most commonly used is the one based on the natural logarithm of returns. Likewise, from the growth of traffic in each year, c1, c2, ..., cn, we calculate their natural logarithms $x 1=\operatorname{Ln}(c 1), x 2=\operatorname{Ln}(c 2), x n=\operatorname{Ln}(c n)$. Traffic volatility shall be expressed as the quasi-standard deviation of return logarithms (growths) traffic:

$$
\sigma=\sqrt{\frac{1}{n-1} \sum_{i=1}^{i=n}\left(x_{i}-\bar{x}\right)^{2}}
$$

By applying these expressions, we obtain for each first generation sections:

Table 2. Traffic growth and volatility in sections corresponding to each concession. Source: self-elaboration.

$\begin{array}{ccc}\text { Section (Stretch) } & \begin{array}{c}\text { Average growth of } \\ \text { traffic in the section }\end{array} & \begin{array}{c}\text { Average volatility of } \\ \text { traffic in the section }\end{array} \\ \text { A1-S2 } & 5,02 \% & 6,52 \% \\ \text { A2-S1 } & 3,65 \% & 13,19 \% \\ \text { A2-S2 } & 5,38 \% & 6,21 \% \\ \text { A2-S3 } & 3,93 \% & 5,48 \% \\ \text { A2-S4 } & 7,66 \% & 10,43 \% \\ \text { A3-S2 } & 7,23 \% & 11,41 \% \\ \text { A3-S3 } & 5,73 \% & 12,22 \% \\ \text { A3-S4 } & 4,13 \% & 6,48 \% \\ \text { A4-S1 } & 5,05 \% & 8,00 \% \\ \text { A4-S3 } & 3,36 \% & 6,10 \% \\ \text { All de sections } & \mathbf{5 , 1 2 \%} & \mathbf{8 , 6 0 \%}\end{array}$




\section{Participation loans as real options}

In essence, a participation loan granted by the Administration, gives the concessionaire a loan whose remuneration depends in some way on turnover. Thus, when the volume of traffic is low, the Administration subsidizes financing; if it is high, it shares revenues through higher pay for the loan. This usually reduces the variance of cash flows and therefore the project risks and financing costs, facilitating the viability of projects.

The remuneration part of the loan that is known, if any, as well as the return of principal, is discounted at risk-free interest rate, because there is no uncertainty about such payments. The remaining loan payments are a series of variable payments whose value can be considered a derivative of the volume of traffic, which acts as the underlying asset. In addition, there are conditions of exercise on certain dates, so it is easy to understand the appropriateness of this methodology for valuing these loans.

According to the terms of the loans, which have been described above, we can see that for the Administration, the variable remuneration loan $\mathrm{R}$ functions as an European put option (Hull, 2006), since it is an annual exercise, in a given time, and has a minimum remuneration for the exercise ( 175 basis points of the outstanding balance of the loan). On the other hand, the $R$ value of the option is limited, because when the actual fee exceeds the maximum canon, $R$ has its maximum value. This is to a certain extent a novelty, because the spirit is that compensation is as high as traffic permits. However, in the present case this is consistent, because beyond a certain maximum traffic, the concessionaire receives no income according to the offers made. Therefore, it would not make sense to increase the cost of financing beyond a certain value, when the concessionaire yields cannot grow.

\section{Valuation of participation loans as real options}

Although there are different methods for determining the value of the participation loans as real options, this paper has chosen the method of simulation for its simplicity and the ease with which the options can be modeled. Assume we have a concession with an expected duration of $N$ years in which the payment of interest in the interval $(t, t+d t)$ is defined in terms of the existent traffic in the concession in that interval, $\theta \mathrm{t}$, that is to say $\mathrm{Rt}=\mathrm{ft}(\theta \mathrm{t})$. We also consider that $\theta t$ evolves over the period considered as a Geometric Brownian Motion (Lara-Galera and Sanchez-Soliño, 2010) of constant parameters (defined above) $\alpha$ and $\sigma$. This is a common assumption in the traffic modeling as a diffusion process. There is another stochastic process $\theta$ t adjusted associated to $\theta t$ (Hull, 2006):

$$
\frac{d \theta_{t}}{\theta_{t}}=\alpha d t+\sigma d z ; \frac{d \theta_{t}^{\text {adjusted }}}{\theta_{t}^{\text {adjusted }}}=(r-\delta) d t+\sigma d z
$$

Being $\theta 0=\theta 0$ adjusted. From this adjusted process, we can determine the certainty equivalent of any future value of assets whose volatility comes induced by our state variable, traffic, moving in a universe of risk neutrality. Although traffic is a non-financial variable, note that this procedure allows us to treat it as if it were, being a necessary requirement to consistently apply the valuation of options.

By analogy with financial assets, we can define a rate of return $\mu$ of the active "traffic" that must satisfy the Capital Asset Pricing Model (Sharpe, 1964). Furthermore, we also know that for any asset, the total rate of return equals its revaluation (growth rate appreciation) and dividend generated by such asset. So, $\mu=r+\beta(r m-r)=\alpha+\delta$, where $r$ is the riskfree return, $r m$ the market returns and $\beta$ the coefficient correlating traffic volatility in relation to the market (LaraGalera, 2006). Taking into consideration that the $\beta$ coefficient can be related to the price of traffic risk $\lambda$ considered as a financial asset (Dixit and Pindyck, 1994), operating and grouping terms we have:

$$
\alpha^{\text {adjusted }}=r-\delta=\alpha-\beta\left[r_{m}-r\right] ; \lambda=\frac{\mu-r}{\sigma}=\frac{\alpha+\delta-r}{\sigma}=\frac{\mu_{\text {project }}-r}{\sigma_{\text {project }}} ; \beta=\frac{\sigma}{\sigma_{\text {project }}} \beta_{\text {project }}
$$


Being $\mu$ project and oproject the profitability and volatility of the project, respectively, which can be calculated by simulation. Building on the research of Lara-Galera (2006) and Lara-Galera and Sanchez-Soliño (2010), we can consider that in Spain, a characteristic value for the traffic is $\beta=0.15$. The continuous evolution of the process $\theta$ tadjusted can be approximated using the corresponding discrete-time arithmetic procedure, based on the transformation of Trigeorgis (1995). We define $X t=\operatorname{Ln}(\theta$ tadjusted), whose evolution in discrete time corresponds to $X t+\Delta t-X t$ $=\tau \Delta t+\sigma \varepsilon(\Delta t) 1 / 2$. Where $\varepsilon$ is a normal random variable with mean zero and standard deviation unity and $\tau=\alpha$ adjusted$0,5 \sigma 2$. From $\Delta t$ we can define discrete series of values $X t$ and $\theta$ tadjusted. The value of the option in any year " $j "$ and at any instant $t$ is given by:

$$
R_{j}=\max \left(0,0175 P P_{j}, \frac{1}{2} T \frac{C a R_{j}}{C_{a M_{j}}} P P_{j}\right) ; R_{t}=e^{-r(j-t)} E\left(R_{j}\right)
$$

Where $E$ is the expected value operator. The sum of all payments $R j(j>t, f o r ~ j=t+1, t+2, \ldots)$ at time $t$, give us the value to the Administration (in $\mathrm{t}$ ) of all variable interests received from the concessionaire until the end of the concession. Obviously, considering the initial outlay (principal) made and the repayment of principal at the end of the concession, it is immediate to calculate the Net Present Value (NPV) of the loan for the government and for the concessionaire (which have opposite signs). The value of the option Rt can be determined using the Monte Carlo simulation procedure according to the following scheme:

- We would generate a trajectory of discrete random values Xt to determine the possible evolution of adjusted traffic $\theta t$ adjusted for each of the years of the concession. The number of values to be generated will depend on $\Delta \mathrm{t}$.

- We would calculate the value Rj of the option for each year $\mathrm{j}$.

- We would calculate the NPV in the given time $t$ for this set of values Rj.

- We would repeat the steps above a significant number of times to have enough NPV values and to calculate their expected value.

\section{Results: application to a section of the corridor Madrid-Alicante}

As a practical application, we have chosen one of the sections of the corridor Madrid-Alicante, and the net present value of the participation loan to the concessionaire has been calculated using the Monte Carlo method. This value is equal in absolute value and of opposite sign to the one that the Administration assumes when it grants the loan to the concessionaire. Note that it must be satisfied that:

$$
N P V=P-\sum_{j} R_{j}-\frac{P}{(1+r)^{n}}
$$

where: NPV is the net present value of the loan in 2011, which is the date when the loan was granted; P the loan principal; $\mathrm{Rj}$ is the value in 2011 of each of the variable payments made in the moment "j" or, in other words, the value of each of the options in 2011 maturing in " $\mathrm{j}$; $n$ is the number of years between the year 2011, the date of granting the loan and the year in which the principal is repaid, the last year of the concession; $r$ is the risk-free return.

The representative values of this concession are:

- $\alpha=4.13 \%$

- $\quad$ adjusted $=3.41 \%$

- $\sigma=6.48 \%$

- $\delta=2.26 \%$

- $r f=5.67 \%$. The annual risk-free return has been calculated taking as a reference the interest rate of Spanish $15-$ year bond corresponding to the September 2011 auction.

- $r=5.52 \%$ (continuing value of risk-free return).

- $r m=10.45 \%$. The characteristic market return is determined by averaging the stock market (IBEX-35) profitability for the past 15 years. 
- $\quad$ Loan principal $=€ 33.856 .548$.

- Initial traffic $=1.288 .336 .485 \mathrm{VxKm}$. The concessionaire did not anticipate traffic in his bidding offer for the years 2007 and 2008. However, to simulate the possible evolution of traffic over time, we use the total real value (light + heavy vehicles) of the traffic on the highway in 2007.

- Corrected rate for light vehicles $2007=€ 0.0096 / V x K m$. To restore the financial balance of the concession, the State admitted the correction rate the concessionaire initially offered in the bid. The correction was applied retrospectively since 2010 .

- Rate for heavy vehicles $2007=€ 0.0134 / \mathrm{VxKm}$ (according to the Sheets, $40 \%$ higher than the tariff for light vehicles).

- Percentage of heavy vehicles $=21.30 \%$ (it has been determined as the mean value of the concessionaire's traffic, which in any case are almost constant throughout the life of the project).

- Weighted average tariff $2007=€ 0.0104$ / VxKm.

- Annual tariff growth rate $=2 \%$ (CPI growth assumption set by the specifications of the administrative clauses).

- $\quad$ Project IRR $=6.8 \%$.

- $\tau=3.2 \%$.

- Traffic expected by the concessionaire:

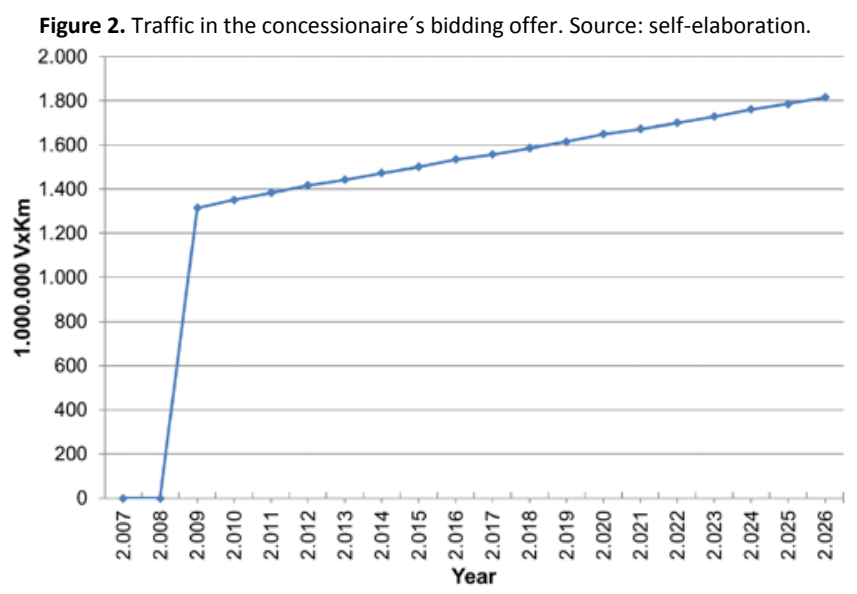

- $\beta=0.15$

- Real Traffic. The evolution has been determined according to the methodology described above.

These data have been used to develop the simulation model. NPV values are calculated for 10.000 simulations in each case.

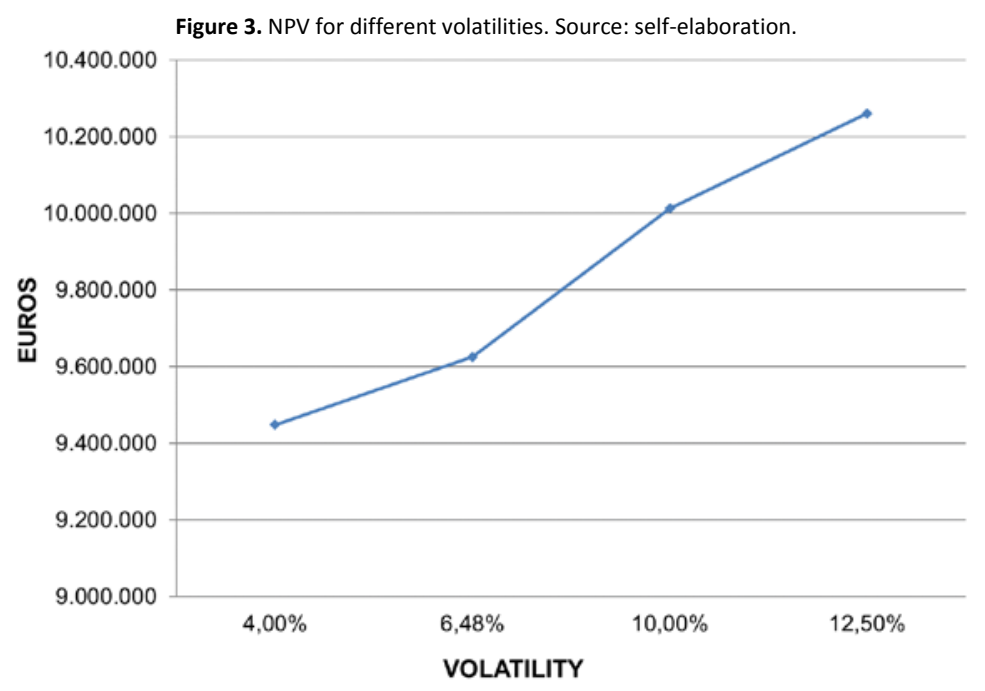


The previous graph shows the value obtained from the NPV of the loan for the concessionaire in 2011(euros) for different values of the volatilities. If we assume that volatility is zero, that is to say, if we assume that traffic evolves in a deterministic way, the NPV in 2011 is equal to 9.398 .090 euros. This value is also obtained if we assume that traffic grows in an extraordinary way, in which case the State would always get maximum compensation. Therefore, this value represents the minimum NPV to the concessionaire, or in other words, the best possible outcome for the State.

If real traffic was much lower than expected by the concessionaire, the State would only obtain the minimum payment on the loan, as it would exercise its option to obtain the remuneration of the strike of the loan. In this case, the NPV in 2011 is 13.666 .627 euros for the concessionaire. The same test has been done for three concessions more and it has been calculated by dividing the value of the NPV of each loan and the principal of the participating loan obtained. It is observed that in all cases this value is approximately 0.3 .

If we assume that, with the same values of the initial case, the loan remuneration that the Administration may receive is not limited, the value obtained for the NPV would be 5.895 .439 euros. This value decreases if the strike increases, raising the interest rate applied (increasing the 175 basis points). It has been observed that for the volatilities obtained, suitably adjusting the interest rate applied depending on the traffic growth expected in this case, the value of NPV could be near zero.

The present work shows that the application of real options method to the valuation of the participation loans is adequate, since it incorporates the value of uncertainty and decision-making rules that are present in this type of instruments. Using traditional valuation techniques generally underestimates the value of the projects as they do not take into account the value of uncertainty and decision-making rules that are present in the contracts, which enable the modification of its results according to the development of events.

The application of the concession system to first generation highways has been a novelty, because it is the first time in Spain that a comprehensive plan to attract private funds for the ordinary and extraordinary maintenance of the motorway network is launched. The payment to the concessionaire is carried out by a shadow toll scheme. However, it is also a novelty that the justified increases of existing works in these contracts are financed through participation loans. Undoubtedly, the main motivation has been to avoid that such increases in the works appear as deficit in the public accounts. On the other hand, the fact that the remuneration of such loans is linked to the volume of business of the concessionaire, especially in regard to traffic volumes, makes it more attractive, since it reduces the variance of the cash flows of the project, making it more feasible.

In this work, the traffic has been modeled as a Geometric Brownian Motion, which is a common assumption in this type of studies. From the analysis of real traffic flows on the highways of the State since 1988, the parameters $\alpha$ and $\sigma$ have been obtained. The average traffic growth is between $3.36 \%$ and $7.66 \%$, with an average value for all awarded sections of $5.12 \%$. In reference to volatility, it is between $5.48 \%$ and $13.19 \%$, with a mean value of $8.60 \%$, so we can state that it is a moderate-risk asset.

As traffic is not a financial variable, the growth rate $\alpha$ has been corrected to use neutral-risk valuation. The valuation of the participation loan was carried out by simulation using the Monte Carlo method, taking as an indicator the project's NPV in 2011, date when the loan was granted. The initial outlet has been used to calculate the NPV, the repayment of principal at the end of the concession period updated to 2011 and the public debt interests, which matches the value in 2011 of a number of options with annual maturity, in which the concessionaire pays the minimum value of the remuneration in relation to traffic or other related to traffic depending on the traffic itself on the exercise date.

For the example discussed, it is observed that for a principal of 33.86 million euros, an initial traffic of 1,288 million VxKm, a drift of $4.13 \%$ and a volatility of $6.48 \%$, the loan NPV is of 9.63 million euros. If traffic was much lower than expected, the State would obtain the minimum remuneration for the loan, with a NPV in 2011 of 13.67 million euros. If traffic was much higher than expected, the NPV would be 9.40 million, the best possible outcome for the State.

It is observed that the used compensation formula distributes traffic risks very asymmetrically between the concessionaire and the State. This is due mainly to having superiorly delimited the remuneration of the loan and because in the chosen example, the traffic expected by the concessionaire is very close to the real traffic. As the most significant summary of the conclusions, we could point out that: 
- From the analysis above, it has become clear that the granting of an equity loan from the State to the companies that hold concession contracts for the maintenance and operation of the first generation highways is a very significant support for the companies.

- The actual NPV value of the loan that is obtained shows, from the State perspective, the cost that this loan entails for itself. Of course, from the opposite perspective of the concessionaire, it means the advantage of accessing this type of financing and not to other contracted with financial institutions on market conditions. From this point of view, the methodology provided in this work can be useful to determine the actual level of the implicit subsidy in such equity loans.

- The situation shows a strong asymmetry, where the most advantageous possibility for the concessionaire speaking strictly in terms of the loan and not the concessional business- would be one in which the traffic generated was minimal. In that case, the State would exercise its option to collect the agreed "floor" (with remuneration interest of 175 basis points), so the cost of borrowing is minimal for the concessionaire and well below the market cost. However, if the opposite situation occurs, with traffic equal or greater than the maximum offered by the concessionaire in the bidding, the loan repayment has a "cap". Traffic increases beyond the maximum stated in the biding offer do not result in increases in the State remuneration, so it would charge a maximum remuneration corresponding to an interest of $0,5 * I R R$, that this case amounts to $3,4 \%$. In the other concession companies, the cap of the State remuneration is very similar.

- The advantage given to the concession companies through this subsidy is due to the low interest rates, below market conditions, and to the fact that the loan principal is not returned until the end of the concession period. Therefore, in the calculation of the loan NPV, as 15 years have elapsed since the granting of it until its cancellation, the quantitative importance of this sum is greatly reduced.

References

Ashuri, B., Kashani, H., Molenaar, K. R., Lee, S., \& Lu, J. (2012). Risk Neutral Pricing Approach for Evaluating BOT Highway Projects with Government Minimum Revenue Guarantee Options. Journal of Construction Engineering and Management, 138(4), 545-557. http://doi.org/10.1061/(ASCE)CO.1943-7862.0000447

B.O.E. Real Decreto-Ley 7/1996, de 7 de Junio, sobre medidas urgentes de carácter fiscal y de fomento y liberalización de la actividad económica (1996). Spain. Retrieved from http://noticias.juridicas.com/base_datos/Fiscal/rdl7-1996.html

B.O.E. Ley 26/2009, de 23 de diciembre, de Presupuestos Generales del Estado para el 2010 (2009). Spain. Retrieved from http://www.minetur.gob.es/

Brandao, L., \& Saraiva, E. (2008). The option value of government guarantees in infrastructure projects. Construction Management and Economics, 28(11), 1171-1180.

Dixit, A. K., \& Pindyck, R. S. (1994). Investment under uncertainty. New Jersey: Princeton University Press.

Engel, E., Fischer, R., \& Galetovic, A. (2013). The basic public finance of public private partnerships. Journal of the European Economic Association, 11(1), 83-111.

Galindo, R., Illueca, M., \& Jimenez, R. (2014). Permanent deformation estimates of dynamic equipment foundations: Application to a gas turbine in granular soils. Soil Dynamics and Earthquake Engineering, 63, 8-18.

Hull, J. C. (2006). Options, Futures and Other Derivatives. (P. P. Hall, Ed.) (6th editio). Upper Saddle River, New Jersey.

Izquierdo, R., \& Vasallo, J. (2004). Nuevos sistemas de gestion de infraestructuras de transporte. (C. y P. de M. Colección Seinor, $n^{\circ} 35$. Colegio de Ingenieros de caminos, Ed.). Madrid: Colegio de Ingenieros de Caminos, Canales y Puertos.

Lara, A. (2006). Desarrollo de un modelo de valoración de concesiones de autopistas basado en la teoría de opciones reales. Validación mediante el análisis de series históricas de datos de concesiones en servicio. Universidad Politécnica de Madrid.

Lara, A., \& Sanchez, A. (2010). A Real Options Approach for the Valuation of Highway Concessions. Transportation Science, 44(3), 416-427.

Ministerio de Fomento (2016) Serie histórica (Mapas) 2000-2009. Mapas de tráfico. Ministerio de Fomento. Madrid. Retrieved from http://www.fomento.gob.es/MFOM/LANG_CASTELLANO/DIRECCIONES_GENERALES/CARRETERAS/TRAFICO_VELOCIDADES/MAPAS/SERIE_HISTORICA/

Sanchez Solino, A., Vassallo, J., Castroman, A., \& Delgado, C. (2007). Nuevo modelo de gestión concesional en autovías de primera generación. Estudios de Construcción Y Transportes, (106), 157-178.

Sharpe, W. F. (1964). Capital asset prices: A theory of market equilibrium under conditions of risk. Journal of Finance, 16, 425-442.

Trigeorgis, L. G. (1995). Real Options in Capital Investment: Models, Strategies, and Applications. (Praeger, Ed.). Westport, CT.

Vassallo, J., \& Sanchez Solino, A. (2007). Subordinated public participation loans for financing toll highway concessions in Spain. Transportation Research Record, 1996, 1-8.

Vassallo, J., \& Solino, A. (2006). Minimum Income Guarantee in Transportation Infrastructure Concessions in Chile. Transportation Research Record: Journal of the Transportation Research Board, 1960, 15-22. http://doi.org/10.3141/1960-03

Wibowo, A. (2004). Valuing guarantees in a BOT infrastructure project. Journal of Construction Engineering and Management, 11(6), 395-403. 